\title{
ERRATUM
}

\section{INTELLECTUAL PROPERTY APPROPRIATION STRATEGY AND ITS IMPACT ON INNOVATION PERFORMANCE}

\author{
[Int. J. Innovation Management, Vol. 20, No. 2 (2016) 1650016]
}

\author{
SAIRAH HUSSAIN \\ Curtin University of Technology \\ Perth WA 6102, Australia \\ sairah.hussain@mymail.unisa.edu.au \\ MILE TERZIOVSKI \\ University of South Australia \\ mile.terziovski@curtin.edu.au
}

Published 7 June 2016

The above affiliations have been changed as shown below:

SAIRAH HUSSAIN should be from University of South Australia and MILE TERZIOVSKI should be from Curtin University of Technology. 